\title{
Baby corn, green corn, and dry corn yield of corn cultivars
}

\author{
Renato S Castro ${ }^{1}$; Paulo Sérgio L Silva ${ }^{1}$; Milton J Cardoso ${ }^{2}$ \\ 'UFERSA, C. Postal 137, 59625-900 Mossoró-RN; paulosergio@ufersa.edu.br; ²Embrapa Meio-Norte, C. Postal 001, 64006-220 \\ Teresina-PI
}

\begin{abstract}
In corn, when the first female inflorescence is removed, the plant often produces new female inflorescences. This allows the first ear to be harvested as baby corn (BC) and the second as green corn (GC) or dry corn (DC), that is, mature corn. The flexibility provided by a variety of harvested products allows the grower to compete with better conditions in the markets. We evaluated BC, GC, and DC yields in corn cultivars AG 1051, AG 2060, and BRS 2020, after the first ear was harvested as BC. A random block design with ten replicates was utilized. The yields of MM, MV and MS were higher when these products were individually harvested than when they were harvested in combination with baby corn $(\mathrm{BC}+\mathrm{GC}$ and $\mathrm{BC}+\mathrm{DC})$. Cultivar BRS 2020 was the best for producing BC exclusively, considering the number and weight of marketable unhusked ears and the number (NH) of marketable husked ears. Considering weight (WH) of BC marketable husked ears, cultivar AG 1051 was the best. Cultivars did not differ in baby corn yield when this product was harvested in combination with MS or MV, except with regard to $\mathrm{NH}$ and $\mathrm{WH}$, with AG 1051 being superior. The cultivars did not differ between total number of ears and number of marketable unhusked green ears. However, cultivars AG 1051 and AG 2060 were the best with respect to marketable unhusked green ears and number and weight of marketable husked green ears. Cultivar AG 1051 was the best with regard to kernel yield.
\end{abstract}

Keywords: Zea mays, green ears, grain, prolificacy.

\section{RESUMO}

Rendimentos de minimilho, milho verde e de grãos de cultivares de milho

No milho, se a primeira inflorescência feminina é removida, existe frequentemente a produção de novas inflorescências femininas. Isso possibilita que a primeira espiga seja colhida como minimilho (MM) e a segunda, como milho verde (MV), ou milho seco (MS), isto é, milho maduro. A flexibilidade proporcionada pela colheita de vários produtos permite ao agricultor competir melhor nos mercados. O objetivo do presente trabalho foi avaliar os rendimentos de MM, MV e MS das cultivares AG 1051, AG 2060 e BRS 2020, após a colheita da primeira espiga como MM. Utilizou-se o delineamento de blocos ao acaso com dez repetições. Os rendimentos de MM, MV e MS foram maiores, quando estes produtos foram colhidos individualmente do que quando eles foram colhidos em combinação com minimilho (MM + MV e MM + MS). A cultivar BRS 2020 foi a melhor para produzir apenas MM, quando foram considerados número e massa de espigas empalhadas comercializáveis e número (ND) de espigas despalhadas comercializáveis. Quanto à massa (MD) de espigas despalhadas comercializáveis de MM, a cultivar AG 1051 foi a melhor. As cultivares não diferiram quanto aos rendimentos de minimilho quando este produto foi colhido em combinação com MV ou MS, exceto quanto ao ND e MD, em que AG 1051 foi superior. As cultivares não diferiram quanto aos números total e de espigas verdes empalhadas comercializáveis. As cultivares AG 1051 e AG 2060 foram as melhores quanto à massa de espigas verdes empalhadas comercializáveis e número e massa de espigas verdes despalhadas comercializáveis. A cultivar AG 1051 foi a melhor quanto ao rendimento de grãos.

Palavras-chave: Zea mays, espigas verdes, prolificidade.

\section{(Recebido para publicação em 6 de março de 2012; aceito em 15 de fevereiro de 2013) (Received on March 6, 2012; accepted on February 15, 2013)}

$\mathrm{C}$ orn exploitation aims to obtain four basic products: baby corn, green ears, grain, and straw. Interest for one or more of those products varies from region to region, but certainly the highest interest is for dry grain. Baby corn consists of corn ears harvested two to three days after silk emergence. It is used as human food, either fresh or in salads. Green ears are immature corn ears whose kernels have a moisture content between 70 and $80 \%$; they are used as human food in a variety of forms. Dry grains are mature grains used as human and animal food as well as for industrial use. Corn straw consists of the above-ground part of the corn plant with or without the ears; in general, it is used in animal nutrition. Cultivars and cultural practices influence yield values of baby corn (Carvalho et al., 2002; Pandey et al., 2002a, 2002b; Thakur et al., 1998), green ears (Almeida et al., 2005; Silva et al., 2007), grain (Ferreira et al., 2009; Strieder et al., 2008), and herbage (Widdicombe \& Thelen, 2002a, b). In addition to the potential exploitation of corn crops as explained above, other uses just begun to be studied and are based on corn prolificacy.

Some corn cultivars are prolific, that is, they have the capacity to produce more than one ear per plant, although only one or two will reach maturity. Prolificacy depends on both genotypic and environmental factors (Motto \& Moll, 1983). A threshold needs to be passed before second ear development occurs. As environmental conditions improve, at some point the conditions are just not sufficient to make the plant pass the threshold to become prolific. At this point all available metabolic energy is used for the enlargement of the apical ear. But when the input is large enough to produce prolificacy, some of the energy otherwise used for the single 
ear now is used for subapical production (Hallauer, 1974).

No matter if a corn cultivar is prolific or not, removal of the first ear normally induces the plant to produce new female inflorescences (Silva, 2001), which may give rise to other ears. This allows the first ear (apical ear) to be harvested as baby corn and the second (subapical) to be harvested as green or mature ear, ensuing flexibility during crop exploitation. The productive potential of the first ear is lower than the second ear (Svečnjak et al., 2006); the hypothesis of our study, however, is that the combined yield of both products can be more advantageous than the yield of each product individually. A study on harvesting baby corn + green corn or baby corn + grain (Silva et al., 2006) showed that the best net incomes from an economic point of view would be obtained by exploiting the crop for the production of green ears, green ears + baby corn, baby corn, baby corn + grain, and grain, in this order (Silva et al., 2006). A study about the theme was conducted by Wang et al. (2010) who compared the followings treatments: 1) no baby corn (BC) harvest, only grain maize (GM) harvest; 2) first harvest as $\mathrm{BC}$, final harvest as GM; 3) first and second harvests as $\mathrm{BC}$, final harvest as GM; and 4) first, second, and third harvests as $\mathrm{BC}$, final harvest as GM. Results indicated that the descending sequence of treatments for economic returns were treatments $4,3,2$, and 1 .

The flexibility provided by harvesting several products from the same crop allows the grower to compete with better conditions in the markets, by offering a wider range of products. Nevertheless, several issues must be addressed relative to cultivars and cultural practices so that the grower can exploit the possibility of producing baby corn and green ears or grain simultaneously. In this respect, the evaluation of several cultivars should be highlighted, in view of the possibility that an interaction between "production systems" $\times$ cultivars may exist.

The objective of this investigation was to evaluate baby corn, green corn, and dry corn yield in three corn cultivars, after harvesting the first ear as baby corn.

\section{MATERIAL AND METHODS}

The experiment was conducted in field at the Universidade Federal Rural do Semi-Árido, located in the district of Alagoinha, $20 \mathrm{~km}$ away from the municipality seat of Mossoró, Brazil ( $5^{\circ} 11^{\prime} \mathrm{S}, 37^{\circ} 20^{\prime} \mathrm{W}, 18 \mathrm{~m}$ altitude), from July to December, 2006. According to Thornthwaite, the climate in the region is semi-arid, and according to Köppen it is classified as BSwh, with two climatic seasons: a dry season that generally lasts from June to January, and a rainy season from February to May. The mean maximum temperature in the region is between 32.1 and $34.5^{\circ} \mathrm{C}$ and the mean minimum is between 21.3 and $23.7^{\circ} \mathrm{C}$, with June and July as the coolest months, while the mean annual precipitation is around $825 \mathrm{~mm}$ (Carmo Filho \& Oliveira, 1989). Insolation increases from March to October, with a mean of $241.7 \mathrm{~h}$; the maximum relative humidity reaches $78 \%$ in April while the minimum is $60 \%$ in September.

According to the Brazilian Soil Classification System, the soil in the experiment area is classified as an Eutrophic Red-Yellow Argisol (Embrapa, 2006), and as a Ferric Lixisol according to the Soil Map of the World (FAO, 1988). The analysis of a soil sample collected at the $0-20 \mathrm{~cm}$ depth showed the following results: $\mathrm{pH}$ in $\mathrm{CaCl}_{2}=5.5 ; \mathrm{OM}=25 \mathrm{~g} \mathrm{dm}^{-3} ; \mathrm{P}=9 \mathrm{mg}$ $\mathrm{dm}^{-3} ; \mathrm{K}^{+}=1.8 \mathrm{mmol}_{\mathrm{c}} \mathrm{dm}^{-3} ; \mathrm{Ca}^{2+}=23$ mmol $\mathrm{dm}^{-3} ; \mathrm{Mg}^{2+}=7 \mathrm{mmol}_{\mathrm{c}} \mathrm{dm}^{-3} ; \mathrm{H}^{+}$ $+\mathrm{Al}^{3+}=18 \mathrm{mmol} \mathrm{dm}^{-3} ; \mathrm{SB}=31 \mathrm{mmol}^{\mathrm{c}}$ $\mathrm{dm}^{-3} ; \mathrm{CEC}=49 \mathrm{mmol}_{\mathrm{c}} \mathrm{dm}^{-3} ; \mathrm{B}=0.34 \mathrm{mg}$ $\mathrm{dm}^{-3} ; \mathrm{Cu}=0.5 \mathrm{mg} \mathrm{dm}^{-3} ; \mathrm{Fe}=33 \mathrm{mg} \mathrm{dm}^{-3}$; $\mathrm{Mn}=16.9 \mathrm{mg} \mathrm{dm}^{-3} ; \mathrm{Zn}=1.1 \mathrm{mg} \mathrm{dm}^{-3}$.

The soil was tilled by means of two harrowings and planting fertilization consisted of $30 \mathrm{~kg} \mathrm{~N}, 60 \mathrm{~kg} \mathrm{P}_{2} \mathrm{O}_{5}$, and 30 $\mathrm{kg} \mathrm{K} \mathrm{O}_{2} \mathrm{O}$ per ha, using ammonium sulfate, single superphosphate, and potassium chloride, respectively. Seeding was performed by hand on 08/01/86 using four seeds per pit. A thinning operation was performed 23 days after sowing, leaving the two more vigorous plants in each pit. Therefore, the programmed sowing stand in the experiment was 50 thousand plants ha ${ }^{-1}$.

The double hybrids AG 1051, AG 2060, and BRS 2020 were submitted to the following production systems: harvest as baby corn; harvest as green ears; harvest as mature ears (dry corn); harvest of the first female inflorescence as baby corn and harvest of the other ears as green corn; harvest of the first female inflorescence as baby corn and harvest of the other ears as mature ears (dry corn). A completely randomized block design was adopted with splitplots (cultivars assigned to plots) and ten replicates. Each subplot consisted of three $6.0 \mathrm{~m}$-long rows spaced 1.0 $\mathrm{m}$ apart with pits spaced $0.4 \mathrm{~m}$ apart. In each subplot the area employed to evaluate corn traits (usable area) was the area occupied by the central row, with the elimination of plants in the last pit at both ends of each row.

The fall armyworm (Spodoptera frugiperda) was controlled with two Deltamethrin sprays ( $5 \mathrm{~g}$ a.i. ha ${ }^{-1}$ ) made 16 and 30 days after sowing, at a dose of $200 \mathrm{~mL} \mathrm{ha}{ }^{-1}$. Weed control was performed by means of two manual hoeings conducted at 23 and 40 days after sowing, respectively. After each hoeing, a sidedressing fertilization was made with $30 \mathrm{~kg} \mathrm{ha}^{-1} \mathrm{~N}$, using ammonium sulfate.

The experiment was sprinklerirrigated, with experimental plots arranged in a parallel fashion with respect to the row of sprinklers. The water depth required for corn $(5.6 \mathrm{~mm})$ was calculated considering a root system operating depth of $0.40 \mathrm{~m}$. Irrigation time was based on the water retained in the soil at a tension of $0.04 \mathrm{Mpa}$. A twoday watering schedule was adopted, with three weekly applications. Irrigation was initiated after planting and suspended 14 days before harvesting the dry corn.

The baby corn was harvested two to three days after silk emergence. Evaluations included the total number and weight of ears; number and weight of marketable ears, both unhusked and husked; length and diameter of husked ears; and green and dry ear weight. Marketable unhusked ears were considered those free from damage caused by pests or diseases, and marketable husked ears were those with good health showing a color varying from pearly white to light yellow, cylindrical in shape, with a diameter 
ranging from 0.8 to $1.8 \mathrm{~cm}$ and length ranging from 4 to $12 \mathrm{~cm}$ (Carvalho et al., 2003). Ear diameter and length were obtained by measuring all husked ears with a digital caliper rule. Green and dry ear weights were estimated for 10 ears per subplot. The ears were weighed and placed in a forced air circulation oven adjusted at $70^{\circ} \mathrm{C}$ until constant weight was achieved.

The green corn was harvested when the grain showed moisture contents between $70 \%$ and $80 \%$. The total number and weight of ears and the number and weight of marketable ears, either unhusked or husked were evaluated. Marketable unhusked ears were considered those free from damage caused by pests or diseases and with a length of $22 \mathrm{~cm}$ or longer, and marketable husked ears were those with good health and grain set, presenting a length of $17 \mathrm{~cm}$ or longer (Silva et al., 2006).

The dry corn was harvested when the kernels showed a moisture content around 20\%. Evaluations were made for number of ears/ha (based on ears harvested from the usable area), number of kernels per ear (in 15 ears taken at random), 100-kernel weight (estimate based on 5 samples), and kernel yield, corrected to a moisture content of $15.5 \%$.

The baby corn was harvested at 56 , $58,61,63$, and 65 days after sowing, while green corn was harvested at 75 , 77, 79, and 82 days after sowing. The dry corn was harvested 131 days after sowing.

The data were submitted to analysis of variance and the means were compared by Tukey's test at 5\% probability, using the SISVAR software program, version 4.3, developed by Universidade Federal de Lavras (Ferreira, 2010).

\section{RESULTS AND DISCUSSION}

There was an effect of the cultivars $\times$ production systems interaction on the number and weight of marketable unhusked baby corn ears, on the number of marketable husked baby corn ears, and on the diameter of husked ears and marketable husked ears (Table 1). In the first two traits, the cultivars did not differ when the first ear was harvested as baby corn and the others were harvested as green corn or dry corn. However, when all ears were harvested as baby corn, cultivar BRS 2060 was more productive than the other two cultivars. This difference in behavior caused the cultivars $\times$ production systems interaction. As to weight of marketable unhusked ears, the lower baby corn ear yield in cultivar AG 2060 when the second ear was harvested as dry corn also contributed toward the

Table 1. Mean number and weight of marketable unhusked baby corn ears/ha, number of marketable husked green baby corn ears/ha, and mean ear diameter of baby corn cultivars, depending on production systems (médias do número e massa de espigas empalhadas comercializáveis de minimilho/ha, do número de espigas despalhadas comercializáveis/ha, e do diâmetro de espigas de minimilho de cultivares de milho, em função de sistemas de produção). Mossoró, UFERSA, 2006.

\begin{tabular}{|c|c|c|c|}
\hline \multirow[b]{2}{*}{ Cultivars } & \multicolumn{3}{|c|}{ Production systems $^{1}$} \\
\hline & Baby corn & $\begin{array}{l}\text { Baby corn }+ \\
\text { green corn }\end{array}$ & $\begin{array}{c}\text { Baby corn }+ \\
\text { dry corn }\end{array}$ \\
\hline & \multicolumn{3}{|c|}{ Marketable unhusked baby corn ears/ha $\left(n^{0}\right)$} \\
\hline AG 1051 & $69,670 \mathrm{Ba}$ & $51,769 \mathrm{Ab}$ & $44,820 \mathrm{Ab}$ \\
\hline AG 2060 & $69,193 \mathrm{Ba}$ & $48,348 \mathrm{Ab}$ & $47,930 \mathrm{Ab}$ \\
\hline BRS 2020 & $92,145 \mathrm{Aa}$ & $50,054 \mathrm{Ab}$ & $49,225 \mathrm{Ab}$ \\
\hline \multicolumn{4}{|c|}{$\mathrm{CV}(\%)_{\text {plots }}=20.1 ; \mathrm{CV}(\%)_{\text {subplots }}=17.7$} \\
\hline & \multicolumn{3}{|c|}{ Marketable unhusked baby corn ears (kg/ha) } \\
\hline AG 1051 & $5,947 \mathrm{Ba}$ & $3,686 \mathrm{Ab}$ & $3,773 \mathrm{Ab}$ \\
\hline AG 2060 & $6,495 \mathrm{Ba}$ & $4,712 \mathrm{Ab}$ & $3,781 \mathrm{Ac}$ \\
\hline BRS 2020 & 7,738 Aa & $4,281 \mathrm{Ab}$ & $4,049 \mathrm{Ab}$ \\
\hline \multicolumn{4}{|c|}{$\mathrm{CV}(\%)_{\text {plots }}=23.7 ; \mathrm{CV}(\%)_{\text {subplots }}=16.8$} \\
\hline & \multicolumn{3}{|c|}{ Marketable husked green baby corn ears/ha $\left(n^{0}\right)$} \\
\hline AG 1051 & $53,744 \mathrm{Ba}$ & $41,152 \mathrm{Ab}$ & $36,359 \mathrm{Ab}$ \\
\hline AG 2060 & $43,840 \mathrm{Ba}$ & $29,183 \mathrm{Bb}$ & $33,025 \mathrm{Ab}$ \\
\hline BRS 2020 & $64,853 \mathrm{Aa}$ & $35,225 \mathrm{ABb}$ & $39,743 \mathrm{Ab}$ \\
\hline
\end{tabular}

\begin{tabular}{llll}
\hline \multicolumn{5}{c}{ Diameter of husked baby corn ears (cm) } \\
\hline AG 1051 & $1.59 \mathrm{Aa}$ & $1.52 \mathrm{Ba}$ & $1.60 \mathrm{Aa}$ \\
$\mathrm{AG} 2060$ & $1.65 \mathrm{Aab}$ & $1.70 \mathrm{Aa}$ & $1.58 \mathrm{Ab}$ \\
$\mathrm{BRS} \mathrm{2020}$ & $1.60 \mathrm{Aa}$ & $1.64 \mathrm{ABa}$ & $1.54 \mathrm{Aa}$ \\
\hline $\mathrm{CV}(\%)_{\text {plots }}=9.0 \% ; \mathrm{CV}(\%)_{\text {subplots }}=6.3 \%$ \\
\hline \multicolumn{5}{c}{ Diameter of marketable, husked baby corn ears (cm) } \\
\hline AG 1051 & $1.50 \mathrm{Aa}$ & $1.47 \mathrm{Aa}$ & $1.51 \mathrm{Aa}$ \\
$\mathrm{AG} 2060$ & $1.51 \mathrm{Aa}$ & $1.50 \mathrm{Aa}$ & $1.49 \mathrm{ABa}$ \\
$\mathrm{BRS} \mathrm{2020}$ & $1.44 \mathrm{Aa}$ & $1.50 \mathrm{Aa}$ & $1.44 \mathrm{Ba}$ \\
\hline $\mathrm{CV}(\%)_{\text {plots }}=4.8 \% ; \mathrm{CV}(\%)_{\text {subplots }}=3.9 \%$ \\
\hline
\end{tabular}

Means followed by the same uppercase letter in the column, and by the same lowercase letter in the row do not differ from one another at $5 \%$ probability, by Tukey test (médias seguidas pela mesma letra maiúscula, na coluna, e pela mesma letra minúscula, na linha, não diferem entre si, a 5\% de probabilidade, pelo teste de Tukey); ${ }^{1}$ baby corn $=$ all ears produced were harvested as baby corn; baby corn + green corn and baby corn + dry corn $=$ the first ear was harvested as baby corn and the others were harvested as green corn or mature corn, respectively $\left({ }^{1}\right.$ minimilho $=$ todas as espigas produzidas foram colhidas como minimilho; minimilho + milho verde e minimilho + milho $\operatorname{seco}=$ a primeira espiga foi colhida como minimilho e as demais como milho verde ou como milho maduro, respectivamente). 
Table 2. Mean weight of marketable ears/ha, length, and weight of husked baby corn ears of different cultivars, depending on the production systems (médias da massa de espigas comercializáveis/ha, e do comprimento e massa de espigas de minimilho despalhadas, de cultivares de milho, em resposta a sistemas de produção). Mossoró, UFERSA, 2006.

\begin{tabular}{|c|c|c|c|c|c|}
\hline \multirow{3}{*}{ Treatments } & \multicolumn{5}{|c|}{ Husked baby corn ears } \\
\hline & \multirow{2}{*}{$\begin{array}{l}\text { Marketable } \\
\text { ears (kg/ha) }\end{array}$} & \multicolumn{2}{|c|}{ Length (cm) } & \multicolumn{2}{|c|}{ Weight (g/ear) } \\
\hline & & Total ears & $\begin{array}{c}\text { Marketable } \\
\text { ears }\end{array}$ & Green & Dry \\
\hline$\overline{\mathrm{AG} 1051}$ & $500 \mathrm{~A}$ & $10.3 \mathrm{~B}$ & $9.8 \mathrm{~B}$ & $11.4 \mathrm{~A}$ & $1.31 \mathrm{~A}$ \\
\hline AG 2060 & $426 \mathrm{~B}$ & $11.4 \mathrm{~A}$ & $10.2 \mathrm{~A}$ & $11.7 \mathrm{~A}$ & $1.29 \mathrm{~A}$ \\
\hline BRS 2020 & $480 \mathrm{AB}$ & $10.7 \mathrm{~B}$ & $10.0 \mathrm{AB}$ & $10.1 \mathrm{~B}$ & $1.18 \mathrm{~B}$ \\
\hline \multirow[t]{2}{*}{$\mathrm{CV}(\%)_{\text {plots }}$} & 23.6 & 9.3 & 5.5 & 14.1 & 13.7 \\
\hline & \multicolumn{5}{|c|}{ Production systems $^{2}$} \\
\hline Baby corn & $599 \mathrm{~A}$ & $10.9 \mathrm{~A}$ & $10.0 \mathrm{~A}$ & $11.3 \mathrm{~A}$ & $1.29 \mathrm{~A}$ \\
\hline Baby corn + green corn & $402 \mathrm{~B}$ & $10.9 \mathrm{~A}$ & $10.0 \mathrm{~A}$ & $10.8 \mathrm{~A}$ & $1.25 \mathrm{~A}$ \\
\hline Baby corn + dry corn & $405 \mathrm{~B}$ & $10.6 \mathrm{~A}$ & $10.0 \mathrm{~A}$ & $11.0 \mathrm{~A}$ & $1.25 \mathrm{~A}$ \\
\hline $\mathrm{CV}(\%)_{\mathrm{sub}}$ & 25.4 & 6.9 & 5.1 & 18.4 & 18.0 \\
\hline
\end{tabular}

In each treatment group, means followed by the same letter do not differ from each other at $5 \%$ probability by Tukey test (em cada grupo de tratamentos, médias seguidas pela mesma letra não diferem entre si, a 5\% de probabilidade, pelo teste de Tukey); ${ }^{2}$ Baby corn $=$ all ears produced were harvested as baby corn; baby corn + green corn and baby corn + dry corn $=$ the first ear was harvested as baby corn and the others were harvested as green corn or mature corn, respectively $($ minimilho $=$ todas as espigas produzidas foram colhidas como minimilho; minimilho + milho verde e minimilho + milho seco $=$ a primeira espiga foi colhida como minimilho e as demais como milho verde ou como milho maduro, respectivamente). above-mentioned interaction. In general, harvesting the first ear as baby corn and the second ear as green corn or dry corn provided lower yields than when all ears were harvested as baby corn.

With regard to the number of husked marketable baby corn ears, cultivars BRS 2020 and AG 1051 were the best when all ears were harvested as baby corn, or when only the first ear was harvested as baby corn and the second ear was harvested as green corn, respectively (Table 1). Such difference in behavior caused the cultivars $x$ growing systems interaction. Again in this case, harvesting the first ear as baby corn and the second ear as green corn or dry corn provided lower yields than when all ears were harvested as baby corn. This certainly occurred because, after harvesting baby corn ears, new inflorescences were being formed, giving rise to new baby corn ears.

With respect to diameter of husked baby corn ears, that interaction resulted from a difference in cultivar behavior

Table 3. Mean total number, total weight, number and weight of both marketable unhusked ears, and number and weight of both marketable husked ears for corn cultivars as a response to different production systems (médias do número e massas totais de espigas verdes, do número e massa de espigas verdes comercializávies, empalhadas e despalhadas, de cultivares de milho em resposta a sistemas de produção). Mossoró, UFERSA, 2006.

\begin{tabular}{|c|c|c|c|c|c|}
\hline \multirow{3}{*}{ Treatments } & \multicolumn{5}{|c|}{ Green corn ears/ha ${ }^{1}$} \\
\hline & \multicolumn{4}{|c|}{ Unhusked } & \multirow{2}{*}{$\begin{array}{c}\text { Marketable } \\
\text { husked ears } \\
\left(\mathrm{n}^{0}\right)\end{array}$} \\
\hline & Total number & $\begin{array}{c}\text { Total weight } \\
(\mathrm{kg})\end{array}$ & $\begin{array}{c}\text { Marketable ears } \\
\left(\mathbf{n}^{0}\right)\end{array}$ & $\begin{array}{c}\text { Marketable ears } \\
\text { (kg) }\end{array}$ & \\
\hline AG 1051 & $49,340 \mathrm{~A}$ & $14,359 \mathrm{~A}$ & $43,966 \mathrm{~A}$ & $13,708 \mathrm{~A}$ & $29,690 \mathrm{~A}$ \\
\hline AG 2060 & $47,134 \mathrm{~A}$ & $13,585 \mathrm{AB}$ & $41,488 \mathrm{~A}$ & $13,003 \mathrm{~A}$ & $30,255 \mathrm{~A}$ \\
\hline BRS 2020 & $45,777 \mathrm{~A}$ & $11,459 \mathrm{~B}$ & $41,066 \mathrm{~A}$ & $10,650 \mathrm{~B}$ & $23,290 \mathrm{~B}$ \\
\hline \multirow[t]{2}{*}{$\mathrm{CV}(\%)_{\text {plots }}$} & 18.7 & 22.3 & 11.0 & 21.9 & 19.7 \\
\hline & \multicolumn{5}{|c|}{${\text { Production systems }{ }^{2}}^{2}$} \\
\hline Green corn & $50,582 \mathrm{~A}$ & $15,990 \mathrm{~A}$ & $48,746 \mathrm{~A}$ & $15,642 \mathrm{~A}$ & $39,548 \mathrm{~A}$ \\
\hline Baby corn + green corn & $44,251 \mathrm{~B}$ & $10,278 \mathrm{~B}$ & $35,600 \mathrm{~B}$ & $9,265 \mathrm{~B}$ & $15,942 \mathrm{~B}$ \\
\hline \multirow[t]{3}{*}{$\mathrm{CV}(\%)_{\text {subplots }}$} & 21.7 & 14.1 & 14.6 & 14.6 & 22.6 \\
\hline & \multicolumn{5}{|c|}{ Husked green ears $(\mathrm{kg} / \mathrm{ha})$} \\
\hline & \multicolumn{2}{|c|}{ Green corn } & \multicolumn{3}{|c|}{ Baby corn + green corn } \\
\hline AG 1051 & \multicolumn{2}{|c|}{$9,360 \mathrm{Aa}$} & \multicolumn{3}{|c|}{$3,171 \mathrm{ABb}$} \\
\hline AG 2060 & \multicolumn{2}{|c|}{$9,853 \mathrm{Aa}$} & \multicolumn{3}{|c|}{$3,657 \mathrm{Ab}$} \\
\hline BRS 2020 & \multicolumn{2}{|c|}{$6,017 \mathrm{Ba}$} & \multicolumn{3}{|c|}{$2,056 \mathrm{Bb}$} \\
\hline
\end{tabular}

$$
\mathrm{CV}(\%)_{\text {plots }}=27.8 ; \mathrm{CV}(\%)_{\text {subplots }}=20.8
$$

${ }^{1}$ In each treatment group, means followed by the same uppercase letter in the column, and by the same lowercase letter in the row do not differ from one another at $5 \%$ probability, by Tukey test (em cada grupo de tratamentos, médias seguidas pela mesma letra maiúscula, na coluna, e pela mesma letra minúscula, na linha, não diferem entre si, a $5 \%$ de probabilidade, pelo teste de Tukey); ${ }^{2}$ Green corn $=$ all ears produced were harvested as green corn; baby corn + green corn = the first ear was harvested as baby corn and the others were harvested as green corn (milho verde $=$ todas as espigas produzidas foram colhidas como milho verde; minimilho + milho verde $=$ a primeira espiga foi colhida como minimilho e as demais como milho verde). 
Table 4. Means for grain yield, number of mature ears, 100-kernel weight, and number of kernels per ear in corn cultivars depending on production systems (médias do rendimento de grãos, número de espigas maduras, peso de 100 grãos e número de grãos por espiga de cultivares de milho em função de sistemas de produção). Mossoró, UFERSA, 2006.

\begin{tabular}{|c|c|c|c|c|c|}
\hline \multirow{2}{*}{ Treatments } & \multirow{2}{*}{$\begin{array}{l}\text { Grain yield } \\
\text { (kg/ha) }\end{array}$} & \multirow{2}{*}{$\begin{array}{c}\text { Ears/ha } \\
\left(\mathbf{n}^{0}\right)\end{array}$} & \multirow{2}{*}{$\begin{array}{l}\text { 100-kernel } \\
\text { weight (g) }\end{array}$} & \multicolumn{2}{|c|}{ Kernels/ear $\left(n^{0}\right)^{1}$} \\
\hline & & & & Dry corn & Baby corn + dry corn \\
\hline AG 1051 & $7,484 \mathrm{~A}$ & $43,863 \mathrm{AB}$ & $36.7 \mathrm{~A}$ & $553.9 \mathrm{Aa}$ & $318.7 \mathrm{Ab}$ \\
\hline AG 2060 & $6,183 \mathrm{~B}$ & $42,839 \mathrm{~B}$ & $36.7 \mathrm{~B}$ & $570.5 \mathrm{Aa}$ & $318.5 \mathrm{Ab}$ \\
\hline BRS 2020 & $5,708 \mathrm{~B}$ & $47,376 \mathrm{~A}$ & $31.8 \mathrm{~B}$ & $425.4 \mathrm{Ba}$ & $312.8 \mathrm{Ab}$ \\
\hline \multirow[t]{2}{*}{$\mathrm{CV}(\%)_{\text {plots }}$} & 17.3 & 11.6 & 9.6 & & 12.1 \\
\hline & \multicolumn{5}{|c|}{ Production systems $^{2}$} \\
\hline Dry corn & $8,602 \mathrm{~A}$ & $49,415 \mathrm{~A}$ & $33.9 \mathrm{~A}$ & & - \\
\hline Baby corn + dry corn & $4,314 \mathrm{~B}$ & $39,970 \mathrm{~B}$ & $33.0 \mathrm{~A}$ & & - \\
\hline $\mathrm{CV}(\%)_{\text {subplots }}$ & 16.3 & 13.1 & 12.5 & & 10.5 \\
\hline
\end{tabular}

${ }^{1}$ In each treatment group, means followed by the same uppercase letter in the column, and by the same lowercase letter in the row do not differ from one another at $5 \%$ probability, by Tukey test (em cada grupo de tratamentos, médias seguidas pela mesma letra maiúscula, na coluna, e pela mesma letra minúscula, na linha, não diferem entre si, a $5 \%$ de probabilidade, pelo teste de Tukey); ${ }^{2}$ Dry corn $=$ all ears produced were harvested as dry corn; baby corn + dry corn $=$ the first ear was harvested as baby corn and the others were harvested as dry corn (milho seco $=$ todas as espigas produzidas foram colhidas como milho seco; minimilho + milho seco $=$ a primeira espiga foi colhida como minimilho e as demais como milho seco).

when the first ear was harvested as baby corn and the others as green corn, and because there were differences in ear diameter for cultivar AG 2060 depending on the various production systems (Table 1). With regard to diameter of marketable husked ears, the interaction occurred because ear diameter in cultivar AG 1051 was higher than ear diameter in the other cultivars when the first ear was harvested as baby corn and the others were harvested as dry corn (Table 1).

In relation to husked baby corn ears, there was no effect of the cultivars $x$ production systems interaction with regard to ear weight, total and marketable ear length, and green and dry ear weight (Table 2). Cultivar AG 1051 performed better on the first trait, cultivar AG 2060 showed the longest ears, and both cultivars produced the heaviest ears. Also, with reference to marketable husked ear weight, harvesting the first ear as baby corn and the second ear as green corn or dry corn provided lower yields than when all ears were harvested as baby corn (Table 2). There were no differences between production systems for the other traits (Table 2).

In addition, there was no effect of the cultivars $\times$ production systems interaction in five of the six traits employed to assess green ear yield (Table 3). There were no differences between cultivars for total number of ears and number of marketable unhusked ears. Cultivar AG 1051 was the top performer for total ear weight and, together with cultivar AG 2060, was the best in terms of marketable unhusked ear weight and number of marketable husked ears. Cultivars AG 1051 and AG 2060 were the best for marketable husked green ear weight when all ears were harvested as green corn, but cultivar AG 2060 was superior when the first ear was harvested as baby corn and the others were harvested as green ears (Table 3). This differential behavior of cultivars caused the cultivars $\times$ production systems interaction. For the six traits indicated in this Table, harvesting the first ear as baby corn and harvesting the second ear as green corn provided smaller means than when all ears were harvested as green corn.

Cultivar AG 1051 performed best for grain yield and 100-mature-kernel weight, while cultivar BRS 2020 performed best for number of mature ears ha ${ }^{-1}$ (Table 4). In those traits, with the exception of 100-kernel weight, harvesting all ears as mature corn provided higher means than harvesting the first ear as baby corn and harvesting the other ears as mature corn (Table 4). With regard to number of kernels per ear there was an effect of the cultivars $\times$ production systems interaction (Table
4). This interaction occurred because the cultivars were different when all ears were harvested as dry corn (with emphasis on the superiority of cultivars AG 1051 and AG 2060), but showed no differences when the first ear was harvested as baby corn. Harvesting all ears as mature corn resulted in a higher mean than harvesting the first ear as baby corn and the other ears as mature corn.

For green corn (Table 3) and dry corn (Table 4), the number of ears formed when the first ear was harvested as baby corn was smaller than the number of ears produced when all ears were harvested as green or dry ears, respectively. In addition, mature ears showed a smaller number of kernels per ear in the baby corn + dry corn production system (Table 4). A similar fact must have occurred with green ears, since there was a reduction in the number (Table 3) and weight (Table 3) of marketable husked green ears. These observations agree with observations made by other authors (Silva et al., 2006) and may have resulted from pollination problems. When the second inflorescence was formed after removal of the first ear, there may not have been pollen grain available to form new ears or fully-set ears.

Pollination deficiencies may have occurred because of the dynamics of 
pollen release in corn. This dynamics tend to follow the Gauss curve, i.e., the amount of released pollen increases with time and then decreases after reaching maximum values (Lizaso et al., 2003). Therefore, inflorescences formed later have a smaller chance of being pollinated because of reduced pollen availability. It is also possible that the weather conditions prevailing during the flowering period, particularly relative humidity and temperature, would have aggravated the reduction in pollination. Hot and dry environments cause a reduction in the viability of corn pollen grains (Purseglove, 1972). In addition, the ovaries that produce late-fertilized ovules frequently abort, thus reducing the formation of grain (Carcova et al., 2000; Anderson et al., 2004). Late silk emergence and incomplete kernel set after subapical ears are pollinated may indicate the occurrence of (Cárcova et al., 2000): a dominance mechanism exercised by the apical ear (Pinthus \& Belcher, 1994); competition for assimilates between ears (Tollenaar et al., 1992); or the simultaneous occurrence of both processes (Bangerth, 1989).

We conclude that baby corn (BC) + green corn $(\mathrm{GC})$ and $\mathrm{BC}+$ dry corn (DC) harvesting provided lower baby corn yields than when all ears were harvested as baby corn. $\mathrm{BC}+\mathrm{GC}$ harvesting provided lower $\mathrm{GC}$ yields than the treatment where all ears were harvested as GC. $\mathrm{BC}+\mathrm{DC}$ harvesting provided lower kernel yield than the treatment where all ears were harvested as DC. Cultivar BRS 2020 was the best for producing $\mathrm{BC}$ exclusively, as to the number (EN) and weight (EW) of marketable unhusked ears and the number $(\mathrm{NH})$ of marketable husked ears. Considering weight (WH) of marketable husked ears, cultivar AG 1051 was the best. There were no differences between cultivars as to $\mathrm{BC}$ yield in $\mathrm{BC}+\mathrm{GC}$ or $\mathrm{BC}+\mathrm{DC}$ harvesting, except with regard to $\mathrm{NH}$ and $\mathrm{WH}$, with AG 1051 being superior. The cultivars did not differ with regard to total number of ears and number of marketable unhusked green ears. However, cultivars AG 1051 and AG 2060 were the best with respect to marketable unhusked green ears and number and weight of marketable husked green ears. Cultivar AG 1051 was the best with regard to kernel yield.

\section{REFERENCES}

ALMEIDA IPC; SILVA PSL; NEGREIROS MZ; BARBOSAZ. 2005. Baby corn, green ear and grain yield of corn cultivars. Horticultura Brasileira 23: 960-964.

ANDERSON SR; LAUER MJ; SCHOPER JB; SHIBLES RM. 2004. Pollination timing effects on kernel set and silk receptivity in four maize hybrids. Crop Science 44: 464-473.

BANGERTH F. 1989. Dominance among fruits/ sinks and the search for a correlative signal. Physiologia Plantarum 76: 608-614.

CÁRCOVA J; URIBELARREA M; BORRÁS L; OTEGUI ME; WESTGATE ME. 2000. Synchronous pollination within and between ears improves kernel set in maize. Crop Science 40: 1056-1061.

CARMO FILHO F; OLIVEIRA OF. 1989. Mossoró: um municipio do semi-árido nordestino. Mossoró: Fundação Guimarães Duque/ESAM. 62 p. (Coleção Mossoroense. Série B. n. 672).

CARVALHO GS; PINHO RGV; RODRIGUES VN. 2003. Produção de minimilho em diferentes ambientes de cultivo. Revista Ceres 50: $155-169$.

CARVALHO GS; PINHO RGV; PEREIRA FILHO I. 2002. Efeito do tipo de cultivar, despendoamento das plantas e da época de semeadura na produção de minimilho. Revista Brasileira de Milho e Sorgo 1: 47-58.

EMBRAPA. Centro Nacional de Pesquisa do Solo. 2006. Sistema brasileiro de classificação de solos. Brasília: Serviço de Produção de Informação. $412 \mathrm{p}$.

FAO. 1988. Soil map of the world, revised legend. Rome: UNESCO. 119 p.

FERREIRA DF. 2010. SISVAR - programa estatístico. Versão 5.3 (Build 75). Lavras: Universidade Federal de Lavras.

FERREIRA AO; SA, JCM; BRIEDIS C; FIGUEIREDO AG. 2009. Desempenho de genótipos de milho cultivados com diferentes quantidades de palha de aveia-preta e doses de nitrogênio. Pesquisa Agropecuária Brasileira 44: 173-179.

HALLAUER AR. 1974. Heritability of prolificacy in maize. Journal of Heredity 65: 163-168, 1974.

LIZASO JI; WESTGATE ME; BATCHELOR WD; FONSECAA. 2003. Predicting potential kernel set in maize from simple flowering characteristics. Crop Science 43: 892-903.
MOTTO M; MOLL RH. 1983. Prolificacy in maize: a review. Maydica XXVIII: 53-76.

PANDEY AK; MANI VP; PRAKASH V; SINGH RD.; GUPTA HS. 2002a. Effect of varieties and plant densities on yield attributes and economics of baby corn (Zea mays). Indian Journal of Agronomy 47: 221-226.

PANDEY AK; PRAKASH V; GUPTA HS. 2002b. Effect of integrated weed-management practices on yield and economics of baby corn (Zea mays). Indian Journal of Agricultural Sciences 72: 206-209.

PINTHUS MJ; BELCHER AR. 1994. Maize topmost axillary shoot interference with lower ear development in vitro. Crop Science 34: 458-461.

PURSEGLOVE JW. 1972. Tropical crops. I. Monocotyledons. New York, John Wiley. $334 \mathrm{p}$.

SILVA PSL. 2001. Desfolha e supressão da frutificação em milho. Revista Ceres 48: 55-70.

SILVA PSL; SILVA PIB; SOUSAAKF; GURGEL KM; PEREIRA FILHO IA. 2006. Green ear yield and grain yield of maize after harvest of the first ear as baby corn. Horticultura Brasileira 24: 151-155.

SILVA PSL; DUARTE SR; OLIVEIRA FHT; SILVA JCV. 2007. Effect of planting density on green ear yield of maize cultivars bred in different periods. Horticultura Brasileira 25: 154-158.

STRIEDER ML; SILVA PRF; RAMBO L; SANGOI L; SILVA AA; ENDRIGO PC; JANDREY DB. 2008. Crop management systems and maize grain yield under narrow row spacing. Scientia Agricola 65: 346-353.

SVEČNJAK Z; VARGA B; BUTORAC J. 2006. Yield components of apical and subapical ear contributing to the grain yield responses of prolific maize at high and low plant populations. Journal of Agronomy and Crop Science 192: 37-42.

THAKUR DR; PRAKASH O; KHARWARA PC; BHALLA SK. 1998. Effect of nitrogen and plant spacing on yield, nitrogen uptake and economics in baby corn (Zea mays). Indian Journal of Agronomy 43: 668-671.

TOLLENAAR M; DWYER LM; STEWART DW. 1992. Ear and kernel formation in maize hybrids representing three decades of grain yield improvement in Ontario. Crop Science 32: 432-438.

WANG Z; STONE M; GRAY E. 2010. Effect of different schedules of baby corn (Zea mays L.) harvests on baby corn yield, grain yield, and economic return. Journal of the Kentucky Academy of Science 71: 59-66.

WIDDICOMBE WD; THELEN KD. 2002a. Row width and plant density effect on forage hybrids. Agronomy Journal 94: 326-330.

WIDDICOMBE WD; THELEN KD. 2002b. Row width and plant density effects on corn grain production in the Northern Corn Belt. Agronomy Journal 94: 1020-1023. 